\title{
The Aetiology of Diabetic Neuropathy: the Combined Roles of Metabolic and Vascular Defects
}

\author{
M.J.Stevens', E.L. Feldman', D.A. Greene ${ }^{a}$ \\ Departments of a Internal Medicine and beurology, and the \\ Michigan Diabetes Research and Training Center, University of \\ Michigan, Ann Arbor, USA
}

\begin{abstract}
A combination of metabolic and vascular defects have been implicated in the pathogenesis of diabetic neuropathy. Animal studies have demonstrated that a reduction in nerve blood flow may be an important early defect and that vasodilators can prevent or ameliorate nerve dysfunction. The potential factors contributing to nerve ischaemia include structural defects in the endoneurial microvasculature together with rheological abnormalities, abnormalities in vasoactive agents which regulate nerve blood flow including nitric oxide and the eicosanoids, and alterations in tone of the autonomic innervation of the nerve vasculature. The principle metabolic defects which have been implicated include disruption of the polyol pathway, altered lipid metabolism, advanced glycosylated end-product formation, increased oxidative stress, and diabetes-induced defects in growth factors. The demonstration that activation of the polyol pathway in experimental diabetes may affect nerve blood flow, and conversely that vasoactive agents appear to be important in regulating some aspects of nerve metabolism, has highlighted the interdependence of the metabolic and vascular defects in the pathogenesis of this condition. Thus, selective intervention aimed at a key defect early in this cascade may subsequently correct a number of later abnormalities offering therapeutic hope in this chronic debilitating complication.
\end{abstract}

KEY WORDS Diabetes mellitus Neuropathy Ischaemia Polyol pathway Nitric oxide Eicosanoids Fatty acid metabolism Growth factors

\section{Introduction}

Diabetic neuropathy is a common complication of diabetes but the mechanisms underlying its pathogenesis have historically received less attention when compared to the renal, eye, and macrovascular lesions which are also frequently present. The recognition of the high prevalence of neuropathy which was found to be present in $39 \%$ of healthy insulin-dependent diabetic patients in the Diabetes Control and Complications Trial (DCCT) ${ }^{1}$ and has been reported to afflict over $50 \%$ of diabetic subjects after 25 years of diabetes ${ }^{2}$ or $44 \%$ of diabetic subjects between 70 and 79 years of age $^{3}$ and its major contribution to sepsis, debility, and lower limb amputations ${ }^{4}$ has stimulated research into its pathogenesis. These studies have provided clues which suggest that many of the mechanisms underlying its pathogenesis may in fact be linked. Thus although the diabetic state undoubtedly leads to a spectrum of abnormalities which lead to the characteristic findings of nerve fibre atrophy and loss, ${ }^{5-8}$ the exciting possibility arises that therapeutic intervention to correct one hyperglycaemia-induced

Correspondence to: Dr M.J. Stevens, Division of Endocrinology and Metabolișm, Department of Internal Medicine, University of Michigan, 5570 MSRB II, Box 0678, 1150 West Medical Center Drive, Ann Arbor, Michigan 48109-0678, USA. defect may subsequently correct a number of abnormalities leading to stabilization or possibility improvement of the neuropathy.

Although the cause of diabetic neuropathy remains unknown its correlation with the degree and duration of the antecedent hyperglycaemia ${ }^{6,9}$ implicates a pathogenesis directly precipitated by the diabetic state. In the DCCT, for example, intensive insulin therapy reduced the appearance of neuropathy at 5 years by up to $69 \% .{ }^{9}$ The resultant effects of the prevailing hyperglycaemia or insulin deficiency precipitating both metabolic $c^{5,10,11}$ and vascular defects ${ }^{12-15}$ in the nerve are highly controversial as is the precise tissue compartment in which these perturbations primarily occur. The principle metabolic defects which have been implicated include disruption of the polyol or sorbitol pathway, abnormalities in lipid metabolism, advanced glycosylated end-product formation, increased oxidative damage, and diabetesinduced defects in growth factors. The factors which may contribute to nerve ischaemia include structural defects in the endoneurial microvasculature together with rheological abnormalities, and abnormalities in vasoactive agents which play a key role in the control of nerve blood flow including the endothelium-derived relaxing factor, nitric oxide and the eicosanoids. It is also unclear whether these diabetes-induced perturbations primarily affect peripheral nerve neurons or the Schwann 
cells, the perineurial or extracellular matrix, the endoneurial vasculature, or perhaps a site remote from the peripheral nerve such as the autonomic ganglia.

This review will focus on the current hypotheses which have been invoked in the pathogenesis of diabetic neuropathy and also evaluate whether they are as divergent as first seems apparent.

\section{Aldose Reductase, The Polyol Pathway, and the Myoinositol Depletion Hypothesis}

Considerable evidence implicates involvement of the polyol pathway in which glucose is metabolized to sorbitol and fructose by the enzymes aldose reductase (AR2) and sorbitol dehydrogenase, respectively, $5,6,10,11,16-18$ in the development of diabetic neuropathy. Glucose-induced alterations in the metabolism of sorbitol, myo-inositol (a precursor for phosphoinositide (PI) synthesis) ${ }^{5,6,10,16,18}$ and taurine (a $\beta$-amino acid) ${ }^{19}$ and their associated effects on $\mathrm{Pl}$ and calcium metabolism have been proposed to be the mechanisms whereby high polyol pathway activity precipitates its deleterious effects.

The myo-inositol depletion hypothesis ${ }^{20-22}$ has for many years been extensively evaluated as the primary polyol-pathway-related defect underlying acute experimental nerve conduction velocity (NCV) slowing. In diabetic rat peripheral nerve the metabolism of glucose via the high $K_{m}$ AR2 promotes sorbitol and fructose accumulation, and myo-inositol depletion, which has been implicated in slowing of nerve conduction. ${ }^{23-26}$ myo-Inositol supplementation or aldose reductase inhibitors (ARIs) normalize nerve myo-inositol and nerve conduction velocity (NCV). ${ }^{23,27-32}$ Thus the action of ARIs on the acute and rapidly reversible slowing of nerve conduction in experimental diabetes is thought to be mediated in part by correction of underlying polyolpathway-induced abnormalities in nerve myo-inositol metabolism. ${ }^{26}$ Depletion of nerve myo-inositol has been proposed to impair incorporation into a class of membrane phospholipids, the phosphoinositides. ${ }^{5,10,18}$ impaired activation of protein kinase C (PKC) by $\mathrm{Pl}$ derived diacylglycerol (DAG) may be the link between altered myo-inositol metabolism and ( $\mathrm{Na}, \mathrm{K}$ )-ATPase regulation in diabetic nerve as a reduction in arachidonylcontaining DAGs and PKC activity has been demonstrated in diabetic rat sciatic nerve. ${ }^{33}$ Moreover exogenous PKC agonists correct impaired nerve ouabain-sensitive energy metabolism and ATPase activity in vitro. ${ }^{34,35}$ Therefore the effect of myo- inositol depletion on ( $\mathrm{Na}, \mathrm{K}$ )-ATPase activity may be mediated through altered $\mathrm{PI}$ turnover and a PKC-dependent mechanism in experimental diabetes. ${ }^{36}$ However, in some diabetic tissues with low polyol pathway activity, glucose may lead to increased de novo synthesis of DAG and PKC activation ${ }^{37,38}$ which mediates a reduction in (Na,K)-ATPase activity. ${ }^{39}$ Therefore PKC activation may either have bi-directional effects on $(\mathrm{Na}, \mathrm{K})$-ATPase activity or chronic stimulation of PKC could poientially lead to compensatory up- or downregulation of its action. Thus it would appear that in tissues with high AR2 activity (such as rat nerve) DAG depletion is the predominant response to hyperglycaemia contrasting with tissues with relatively lower aldose reductase activity (such as retinal capillary endothelium) where DAG accumulation predominates.

The application of the myo-inositol depletion hypothesis to human nerve remains controversial as although ARIs diminish sorbitol accumulation and also increase nerve conduction, nerve myo-inositol is not measurably altered $^{40-42}$ and $(\mathrm{Na}, \mathrm{K})$-ATPase has to date not been assessed.

\section{The $(\mathrm{Na}, \mathrm{K})$-ATPase and Nerve Conduction}

The nerve $(\mathrm{Na}, \mathrm{K})$-ATPase is responsible for the maintenance of the transmembrane ionic gradient which is necessary to facilitate the conduction of electrical impulses. Perturbations in nerve ( $\mathrm{Na}, \mathrm{K})$-ATPase emerged as a possible common denominator for altered energy metabolism, ${ }^{20}$ nerve conduction slowing, and structural abnormalities in acute experimental diabetes based on direct measurement of reduced nerve $(\mathrm{Na}, \mathrm{K})$-ATPase activity in animals, $20,22,43$ its correction by myo-inositol supplementation, ${ }^{44} \mathrm{ARI}$ treatment ${ }^{25,45}$ or prostacyclin analogues. ${ }^{46}$ Moreover pharmacological manipulation of non-diabetic rats with agents which impaired the nerve (Na,K)-ATPase were able to reproduce diabetic nerve conduction slowing. ${ }^{47,48}$ Thus the ability to restore normal nerve ( $\mathrm{Na}, \mathrm{K}$ )-ATPase activity and also correct $\mathrm{NCV}$ has remained central to the metabolic hypothesis of diabetic neuropathy but the mechanism(s) by which diabetes results in its impairment remain controversial.

\section{Osmotic Dysregulation and the Compatible Osmolyte Hypothesis}

For over 20 years, stimulation of AR2 activity by mass action has been viewed as a critical link between hyperglycaemia and the tissue damage underlying some chronic diabetic complications. ${ }^{49-51}$ The view that AR2 is an important physiological intracellular osmoregulator in the renal medulla, where it is induced by extracellular hyperosmolality, has recently emerged as part of a 'compatible osmolyte' hypothesis. ${ }^{51-54}$ This hypothesis argues that non-ionic and therefore, 'non-perturbing' ${ }^{52}$ compounds such as sorbitol, myo-inositol, and taurine, function as alternative organic intracellular osmolytes responding coordinately to changes in external osmolality, thereby buffering injurious shifts in the intracellular electrolyte and water composition. ${ }^{52-54}$

Osmolar stress precipitates compensatory alterations in the intracellular concentration of these alternative osmolytes by induction or suppression of the relevant synthetic enzymes (AR2 in the case of sorbitol ${ }^{55}$ ) or membrane transporters (the sodium-myo-inositol, and taurine transporters $)^{56,57}$, thus accumulating or disposing 
of these osmolytes in a coordinated fashion. Although initially regarded as metabolically inert, these osmolytes are now thought to have important metabolic as well as osmoregulatory roles. 5,50,51,54,58-60 Thus myo-inositol may become limiting for $\mathrm{Pl}$ signalling, ${ }^{59}$ and taurine depletion may lead to disruption of intracellular calcium homeostasis, ${ }^{60}$ neuronal hyperexcitability, ${ }^{61}$ and defects of neurotransmitter release and ion conductance. ${ }^{62,63}$ Given the osmoregulatory and metabolic importance of taurine and myo-inositol, abnormal expression of the osmo-responsive genes that modulate compatible osmolyte metabolism might exaggerate the deleterious effects of otherwise trivial osmolar and/or metabolic stress, such as might occur in diabetes mellitus, thereby predisposing to the development of diabetic neuropathy. Indeed, provocative, fragmentary but conflicting data suggest a possible association between increased AR2 enzymatic activity and/or protein and the presence of late diabetic complications. ${ }^{64-66}$

\section{Disturbances in Cellular Redox}

Increased flux through AR2 and sorbitol dehydrogenase oxidizes the NADPH/NADP ${ }^{+}$and reduces the NADH/ $\mathrm{NAD}^{+}$redox couples, respectively, thereby perturbing other adenine nucleotide-linked reactions. Therefore activation of the polyol pathway in diabetes may lead to metabolic defects by mechanisms involving osmotic perturbations as considered above, or by redox disturbances (Figure 1). Increased oxidative tissue damage in diabetes has been proposed to result from oxidation of the NADPH/NADP ${ }^{+}$couple through depletion of reduced glutathione, although direct supporting evidence is lacking. ${ }^{67}$ Depletion of NADPH may also affect the synthesis of the potent vasodilator and neuromodulator nitric oxide (NO) as both nitric oxide synthase (NOS) and AR2 utilize NADPH as a cofactor. Thus potentially consumption of $\mathrm{NADPH}$ by AR2 may lead to NO depletion with secondary effects on nerve blood flow (and nerve $\mathrm{Na} / \mathrm{K}$ ATPase (considered below). The reduction of $\mathrm{NADH} /$ $\mathrm{NAD}^{+}$coupled to the oxidation of glucose-derived sorbitol to fructose manifest as an increase in the

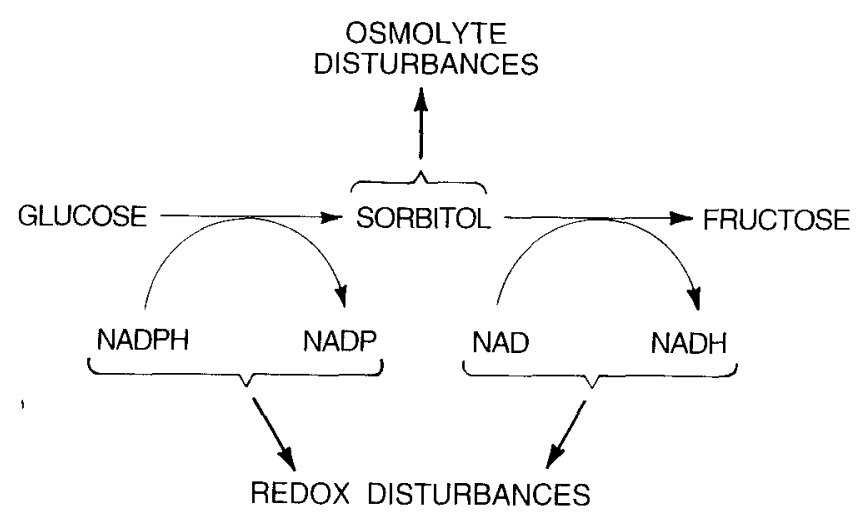

Figure 1. Potential effects of activation of the polyol pathway in diabetes lactate:pyruvate ratio (or 'pseudoischaemia') has also been stressed as the major defect contributing to the development of neuropathy. ${ }^{68}$ This would divert glycolytic intermediates to the synthesis of phospholipid precursors such as alpha-glycerophosphate, phosphatidic acid, DAG and cytidine-diphospho-diglyceride (CDPDG), while at the same time interfering with $\beta$-oxidation of long-chain fatty acids. ${ }^{68}$ The beneficial effects of myoinositol administration on NCV in diabetic rodents would thereby be explained by accelerated disposal of the excess DAG and CDP-DG through the stimulation of PI synthesis. ${ }^{68}$ These observations are currently being assessed in both cell culture and animal models.

\section{Nerve Ischaemia in Diabetes}

There is now increasing evidence that nerve ischaemia plays a central role in the pathogenesis of diabetic neuropathy. Studies in anaesthetized rats have identified reduced endoneurial blood flow and oxygen tension, and increased endoneurial vascular resistance after 4 months of streptozotocin diabetes. ${ }^{69,70}$ A $40 \%$ reduction in nerve blood flow has been observed as early as 1 week after the induction of diabetes in the rat. ${ }^{13}$ Not all investigators agree with the concept of an early reduction in nerve blood flow in experimental diabetes, as microsphere experiments in acutely diabetic rats have suggested increased blood flow and vascular permeability. ${ }^{71}$ Support for a leading role of a reduction of nerve blood flow early in diabetes in the development of NCV slowing is provided by the ability of vasodilatory agents to partially or completely correct nerve conduction slowing. ${ }^{14,15}$ For example, the alpha-adrenergic receptor inhibitor prazosin prevented slowing of conduction in the tibial motor and saphenous sensory nerves in acutely streptozotocin-diabetic rats ${ }^{14}$ and the angiotensin converting enzyme inhibitor lisinopril has been found to prevent $75 \%$ of the slowing of sciatic motor and sensory NCV after 2 months of diabetes. ${ }^{15}$ Lisinopril treatment also increased sciatic nerve capillary density, leading to the conclusion that lisinopril treatment reduced peripheral vascular resistance and increased nerve blood flow by stimulating angiogenesis. The nature of the underlying pathology leading to reduced nerve blood flow remains, however, the subject of controversy.

The concept of nerve ischaemia in diabetes is however not new: Fagerberg's early autopsy studies demonstrated thickened endoneurial vessel walls, which stained $p$ aminosalicylic acid positive and occluded endoneurial microvessels. ${ }^{72}$ A hypoxic hypothesis states that chronic experimental diabetic neuropathy, which is analogous to human diabetic neuropathy, is the result of initial damage to the nerve microvessels, with resultant nerve fibre degeneration secondary to endoneurial hypoxia. ${ }^{70}$ Suggested clinical evidence in support of nerve hypoxia in the development of neuropathy has been the finding of a reduction of endoneurial oxygen in the sural nerves of diabetic patients with polyneuropath $y^{73}$ and the 
development of abnormalities of neural conduction in people with hypoxia secondary to chronic obstructive airway disease. ${ }^{74,75}$ Non-diabetic animals exposed to chronic hypoxia, show some impairment of NCV, and resistance to ischaemic conduction block, abnormalities of which are reversible when the hypoxia is corrected ${ }^{76}$ and experimentally-induced reduction in caudal nerve action potential can be normalized by hyperbaric oxygenation, but without improvement in NCV. ${ }^{77}$ Thus although hypoxia may play a role in the development of diabetic neuropathy, this may not to be the sole factor.

An understanding of both the anatomy of the nerve vasculature as well as the local (i.e. vasoactive agents) and distant (sympathetic tone) factors which regulate nerve blood flow may help elucidate the pathogenetic mechanisms which contribute to ischaemia. The vascular supply of nerve is provided by both an intrinsic system consisting of microvessels which are situated longitudinally within the fascicular endoneurium and an extrinsic system composed of the larger nutritive arteries, arterioles, venules, and epineural vessels. The nerve has only a very limited capacity to autoregulate its vascular supply: perhaps only the epineural and perineural vessels are capable of autoregulation, thus alterations in systemic pressure lead to passive fluctuations of perfusion in the nerve. ${ }^{69,78}$ Extensive anastomoses (both arteriovenous and arterioarterial) are formed between the two systems by the epi- and perineural vessels, which together with the low metabolic requirements of the nerve confer a resistance to ischaemic insults. ${ }^{79}$ However, the recent demonstration of extensive perineurial AV anastomoses in subjects with diabetic neuropathy has led to speculation regarding the role of a 'vascular steal phenomenon' occurring, in which the nutritive endoneurial capillary flow is impaired by the high shunt flow. ${ }^{80}$

A number of vascular endoneurial abnormalities have been found in diabetes which have been suggested to implicate ischaemia as the primary pathogenetic defect leading to neuropathy. Defects identified include basement membrane thickening and duplication, endothelial cell swelling and proliferation, intimal and smooth muscle cell proliferation, capillary closure, and furthermore vessels from autopsy specimens of sural nerve have been found to be occluded by platelet thrombi. ${ }^{72,81-86}$ The interpretation of both the cause and the effects of these histological observations is not, however, straightforward as other studies have failed to find evidence of increased frequency of endothelial cell abnormalities in sural nerves of neuropathic diabetic patients $^{87}$ and suggested that differences in age may be responsible for the differences observed by other investigators. Furthermore, the non-uniform loss of myelinated fibres in diabetic sural nerves in patients with polyneuropathy, which has been taken to indicate nerve ischaemia, was also found in patients with Type 1 hereditary motor and sensory neuropathy, which is not thought to have a vascular basis. ${ }^{88}$ Thus the interpretation of nerve vascular histological abnormalities in diabetic patients remains controversial. These difficulties do not however exclude a significant ischaemic component in the development of neuropathy which appears likely in view of the accumulating evidence from animal studies.

\section{Rheological Abnormalities}

The contribution of rheological abnormalities in diabetes to the pathogenesis of diabetic neuropathy remains uncertain. Potentially at least, diabetic patients may have an increased susceptibility to intravascular thrombosis as whole blood viscosity is increased ${ }^{89,90}$ as is red cell aggregation and fibrinogen levels. ${ }^{91}$ One study which addressed the role of abnormal rheology in the pathogenesis of diabetic distal symmetrical neuropathy, failed to find a difference in rheological abnormalities in patients who developed neuropathy, compared to diabetic subjects without neuropathy. ${ }^{92}$ The study did however confirm that blood viscosity was increased and red cell deformability was reduced in all the diabetic patients. If there is a primary abnormality of the neuronal microvasculature, with resultant reduction in the luminal area, neural blood flow may be compromised by the abnormal rheology in the diabetic state, as vessel radius primarily determines blood flow.

\section{Altered Synthesis, Release, and Sensitivity to Vasoactive Factors in Diabetes}

The mechanisms underlying the decrease in nerve blood flow seen in experimental diabetic neuropathy are unknown but depletion of $\mathrm{NO}^{93}$ or an imbalance of the thromboxane:prostacyclin ratio, leading to a predominance of vasoconstricting eicosanoids, ${ }^{94}$ may potentially result in alterations in sympathetic tone and basal vascular tone with the net result of a reduction of endoneurial blood flow.

\section{Nitric Oxide}

Over the last few years the diverse biological functions of the endothelium-derived relaxing factor NO have become increasingly apparent. This highly reactive, short-lived radical gas has been shown to mediate vasodilatation and macrophage cytotoxicity, and to play an important role as a neuronal messenger within the CNS. ${ }^{93,93,96}$ Recently, its importance in the pathogenesis of diabetic complications, including diabetic neuropathy, has been the subject of increasing interest. Endoneurial endothelial cells, smooth muscle cells, pericytes, and sympathetic ganglia are also most likely sites of nitric oxide synthase (NOS), the enzyme catalysing the conversion of 1-arginine to citrulline and $\mathrm{NO} .{ }^{97}$ In the endothelium and neuron, NOS is calcium-calmodulin dependent and increases in intracellular calcium stimulate its activity. ${ }^{91}$ Locally released $\mathrm{NO}$ in the endoneurial microvasculature would, along with locally derived 
prostacyclins, presumably exert a potent vasodilatory effect which modulates regional blood flow. Endotheliumdependent relaxation of smooth muscle has been shown to be impaired in both human ${ }^{98}$ and experimentally induced diabetes. ${ }^{99-101}$ The mechanisms underlying this deficit are unclear but may involve depletion of $\mathrm{NO}^{99-105}$ or altered smooth-muscle sensitivty to NO. ${ }^{106}$ Impaired local synthesis of NO may alter basal vascular tone either by reduced activation of soluble guanylate cyclase in vascular smooth muscle $e^{101,107,108}$ or by decreased $\mathrm{Na} / \mathrm{K}$-ATPase ${ }^{109}$ potentially resulting in decreased endoneurial blood flow. The impaired endoneurial vasodilatory responses to acetyl choline $\mathrm{c}^{99,100}$ but preserved endothelial-independent vasodilatory responses to, for example, sodium nitroprusside, ${ }^{101}$ nitroglycerin, ${ }^{100,102}$ and other agents which directly release NO, implicate a defect or defects in either endoneurial NO synthesis or release as the cause of impaired vascular responses in diabetes.

Alternatively, although local endoneurial NO depletion may directly contribute to decreased endoneurial blood flow, the potential of NO as an inhibitory neurotransmitter ${ }^{110}$ and its role in the maintenance of blood pressure via modulating sympathetic tone $\mathrm{e}^{93}$ suggest another possible mechanism. The acute reduction in endoneurial blood flow in diabetes may be mediated by acutely increased sympathetic tone, as inhibition of basal sympathetic vascular tone by guanethidine restores both nerve blood flow and nerve conduction to normal levels in acute experimental diabetes. ${ }^{13}$ If $\mathrm{NO}$ is functioning as an inhibitory neurotransmitter, it is tempting to speculate that postsynaptic neuronal NO might dampen presynaptic acetylcholine release thereby modulating peripheral sympathetic tone ${ }^{5}$ (Figure 2 ). Thus in diabetes, if NO depletion at the level of the sympathetic ganglia is an early event, this may result in increased vasocon- stricting sympathetic tone to the nerve vasculature precipitating nerve ischaemia and acute nerve conduction slowing.

Altered NO metabolism in diabetes may be the means by which the divergent metabolic and vascular hypotheses evoked in the pathogenesis of diabetic neuropathy are joined. ${ }^{5,111}$ Metabolic competition for NADPH by AR2 and NOS has been proposed as a potential mechanism by which these hypotheses are linked ${ }^{5,47,111}$ (Figure 3). AR2-mediated consumption of NADPH may not only directly impair the activity of NOS, but may also lead to increased levels of superoxide radicals, as NADPH is also required for the production of reduced glutathione. ${ }^{112}$ The diabetic endothelium is abnormally sensitive to damage mediated by both increased production of superoxide radicals ${ }^{102}$ which may also destroy $\mathrm{NO},{ }^{102,103}$ and to the increased formation of advanced glycosylation end products by glucose ${ }^{112}$ and fructose. Support for metabolic competition between NOS and AR2 is provided by the fact that ARIs not only restore osmolyte balance in the nerve $5,10,19,29,30$ but also improve nerve blood flow. ${ }^{114}$ Moreover, in a 3 -month STZ-D rat model ARI treatment has been demonstrated to restore endotheliumdependent relaxation to within normal limits. ${ }^{111}$ Recently, an NOS inhibitor l-nitro- $\mathrm{N}$-methyl arginine ester (1NAME) was found to reverse the beneficial effects of an ARI in acute experimental diabetic neuropathy, in spite of a significant decrease in nerve sorbitol and an increase in nerve myo-inositol levels. I-NAME was also found to slow NCV and reduce $\mathrm{Na} / \mathrm{K}$-ATPase activity in chronically (3-month) treated non-diabetic animals. ${ }^{47}$ These data support a role for $\mathrm{NO}$ in mediating, at least partially, the beneficial effects of ARIs on nerve blood flow and NCV slowing and also a role in the maintenance of the nerve $\mathrm{Na} / \mathrm{K}$-ATPase, thus suggesting both a vascular and metabolic action.

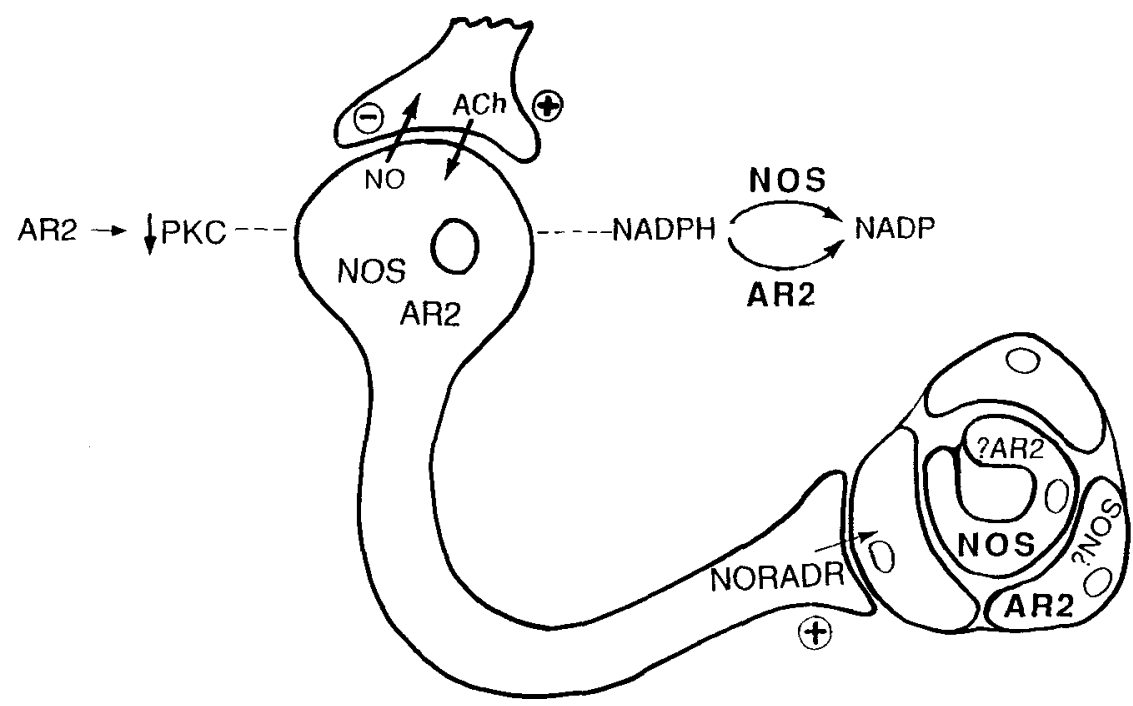

Figure 2. Sympathetic ganglia, smooth muscle cell, and endothelial cell. Depletion of nitric oxide (NO) at the level of the autonomic ganglia or within the endoneurial vasculature may contribute to reduced nerve blood flow in diabetes. AR2, aldose reductase; PKC, protein kinase $\mathrm{C}$; ACh, acetyl choline; NOS, nitric oxide synthase; NORADR, noradrenaline 
NORMAL

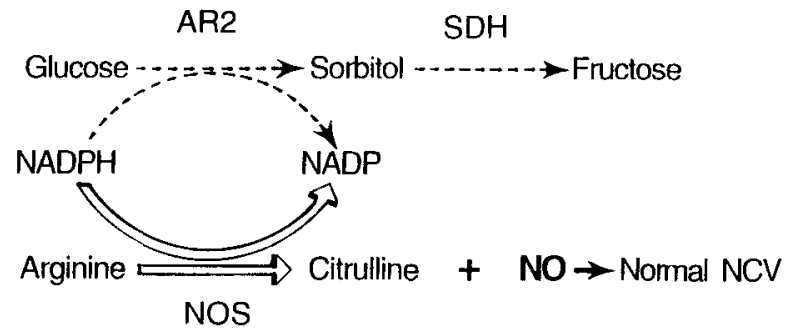

DIABETIC

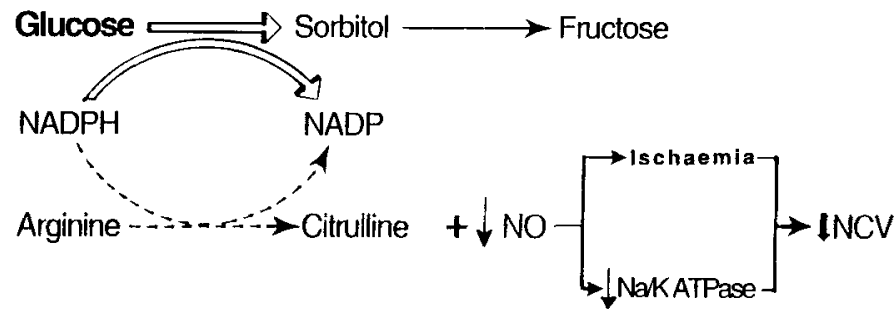

Figure 3. Metabolic competition for NADPH by aldose reductase and nitric oxide synthase in normal and diabetic state. AR2, aldose reductase; $\mathrm{SDH}$, sorbitol dehydrogenase; $\mathrm{NO}$, nitric oxide; $\mathrm{NOS}$, nitric oxide synthase; $\mathrm{NCV}$, nerve conduction velocity

Evidence is also accumulating that PKC may regulate NOS by direct phosphorylation. ${ }^{115-117}$ The effect of PKC on NO synthesis is however controversial as PKC activation has been reported to either increase ${ }^{115}$ or decrease $^{116,117}$ NO synthesis. Moreover, the bi-directional effects of hyperglycaemia on DAG levels and PKC activation which may reflect variations in AR2 expression and activity in different tissues (Figure 4) suggests that tissue-specific differences in these regulatory factors may determine the predominant response of NOS to hyperglycaemia. Potentially, hyperglycaemia may diminish NO synthesis in autonomic ganglia via inhibition of basal PI turnover and PKC activity. This may increase vascular sympathetic tone, resulting in decreased endoneurial blood flow thereby linking metabolic and vascular defects in diabetes.

Therefore a decrease in the synthesis or release of $\mathrm{NO}$ or altered tissue sensitivity to $\mathrm{NO}$ in diabetes could contribute to NCV slowing by decreasing endoneurial blood flow both by acutely increasing vascular sympathetic tone and by localized vascular endothelial and smooth muscle depletion. Moreover, NO depletion may

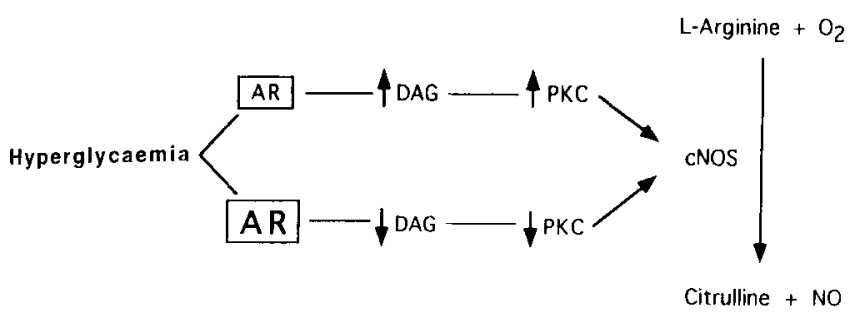

Figure 4. Interactions of aldose reductase gene expression, protein kinase $C$ activation, and nitric oxide synthesis. $A R$, aldose reductase; DAG, diacylglycerol; cNOS, constitutive form of nitric oxide synthase, NO, nitric oxide; PKC, protein kinase $\mathrm{C}$ exert more distal effects on nerve function independently of nerve blood flow via direct effects on the nerve $\mathrm{Na}$ / K-ATPase activity: ${ }^{47,109}$ NO may modulate PI turnover ${ }^{118}$ and thus act synergistically with osmotically-induced myo-inositol depletion in impairing signal transduction and $\mathrm{Na} / \mathrm{K}$-ATPase regulation.

\section{Prostaglandin Metabolism}

Diabetes-induced abnormalities in eicosanoid metabolism may potentially have wide-ranging effects on nerve function. In diabetes, an increase in the thromboxane: prostacyclin ratio ${ }^{94}$ may contribute to nerve ischaemia (and reduced nerve $\mathrm{Na} / \mathrm{K}$-ATPase). Increases in vasoconstricting thromboxanes $\mathrm{PGH}_{2}{ }^{119} \mathrm{Tx}_{2},{ }^{120} \mathrm{PGF} 2 \alpha$, and reduction in vasodilating prostacyclin have been described in isolated diabetic vascular tissue. ${ }^{127}$ Microvascular tone is dependent on the opposing actions of endothelial prostacyclin, which together with $\mathrm{NO}$ elicits vasodilatation, and thromboxane $A_{2}$, which is found mainly in blood platelets and produces vasoconstriction. ${ }^{120}$ Ischaemia in the nerve may activate phospholipase $\mathrm{A}_{2},{ }^{122}$ disrupting membrane phospholipids and generating prostaglandins from activated arachidonic acid $^{123}$ (Figure 5). A hypoxic insult may also be one of the triggers for the production of the superoxide radical via the breakdown of ATP. ${ }^{69}$ The generation of lipid hydroperoxides by the action of free radicals may result in increased cyclooxygenase activity and a reduction in prostacyclin synthetase activity, thus increasing the thromboxane:prostacyclin ratio, with resultant vasoconstriction and platelet aggregation. Phospholipase activation may also generate endothelium disrupting leukotrienes. Eicosanoids may serve to limit the detrimen- 


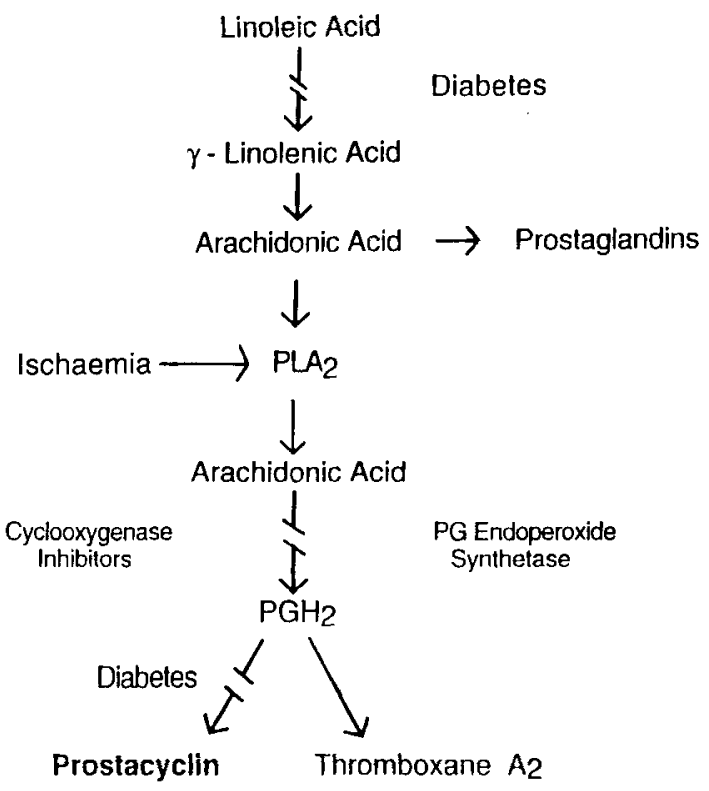

Figure 5. Prostaglandin synthesis in diabetes. PLA 2 , phospholipase $\mathrm{A} 2 ; \mathrm{PGH}_{2}$, prostaglandin endoperoxide $\mathrm{H} 2$

tal effects of ischaemia by inhibiting superoxide anion production. ${ }^{124}$

Compelling evidence in the diabetic rat model implicates a role for disruption of prostaglandin metabolism in NCV slowing. Although nerve prostacyclin levels are typically not depleted early in experimental neuropathy, ${ }^{94}$ altered prostaglandin metabolism at other sites may contribute to the early decrease in endoneurial blood flow as both $P G E_{1}$ and $P G E_{2}$ inhibit sympathetic neurotransmission mainly by reducing the release of noradrenaline from adrenergic nerve terminals. ${ }^{125,126}$ Reduced nerve prostacyclin has been found in chronic (4-month) experimental diabetes ${ }^{94}$ and prostaglandin $E_{1}$ analogue administration has been shown to restore NCV to normal in diabetic rats. ${ }^{114}$ As levels of cAMP have been found to be reduced in experimental neuropathy ${ }^{127}$ and there exists a direct correlation between nerve prostacyclin levels, CAMP, ${ }^{127}$ and the Na/K-ATPase ${ }^{128}$ which are corrected by prostaglandin $E_{1}$ administration, then the possibility arises that prostaglandin metabolism may be a key modulator of the both endoneurial blood flow and nerve $\mathrm{Na} / \mathrm{K}$-ATPase activity. Moreover therapeutic manipulations which have been shown to correct nerve conduction slowing such as myo-inositol supplementation or gamma-linolenic acid (GLA- from evening primrose oil) ${ }^{16,18,23,24,29,129,130}$ may in fact be working at least partly by increasing prostacyclin production as both may potentially increase arachidonic acid which is rate limiting for prostaglandin synthesis.

\section{Carnitine Metabolism}

Abnormalities in fatty acid metabolism have also been implicated in the pathogenesis of neuropathy as diabetesinduced defects in the desaturation of gamma-linoleic acid to gamma-linolenic acid exist ${ }^{130,131}$ which may precipitate a reduction in nerve blood flow via a decrease in production of vasodilating eicosanoids ${ }^{94}$ (Figure 5) and by the accumulation of toxic long chain fatty acids in the peripheral nerve.

Abnormal carnitine metabolism in diabetes may also predispose to the development of diabetic neuropathy. Carnitine and its acetyl ester acetyl l-carnitine play a central role in fatty acid metabolism and are important in the production of the metabolic fuels. ${ }^{132,133} \mathrm{~A}$ reduction in plasma free carnitine and an increase in the carnitine esters has been found in diabetes ${ }^{134,135}$ and this may lead to the accumulation of long-chain fatty acids which can perturb membrane stability ${ }^{136}$ and function ${ }^{137}$ and disrupt energy production in the nerve. ${ }^{138,139}$ Carnitine and acetyl l-carnitine promote transport of cytosolic long-chain fatty acids across the inner mitochondrial membrane to undergo $\beta$-oxidation and may thereby prevent their excessive accumulation. ${ }^{135-142}$ Acetyl 1-carnitine may have neurotrophic properties as it facilitates the neurite outgrowth of rat phaeochromocytoma cells (PC12) to nerve growth factor $^{143}$ (NGF) and stimulates nerve growth factor receptor (NGFR) synthesis in PC12 cells by increasing NGFR protein and mRNA (144). Acetyl-l-carnitine also enhances nerve fibre repair and regeneration after nerve transection $^{14.5}$ in non-diabetic rats and has cholinergic properties. ${ }^{146-148}$ Polyol pathway-induced accumulation of NADH precipitating a metabolic 'pseudohypoxia' has also been implicated in tissue fatty acid accumulation, ${ }^{68,149}$ and may thus also be amenable to acetyl 1carnitine treatment. Finally, acetyl-1-carnitine may affect arachidonic acid metabolism, enhancing the production of prostacyclin which may improve both nerve blood flow and correct reduced nerve $\mathrm{Na} / \mathrm{K}$-ATPase. Preliminary studies have suggested that acetyl l-carnitine can prevent slowing of nerve conduction in streptozotocin-diabetic rats $^{140,141}$ and vascular dysfunction ${ }^{142}$ although the mechanisms remain obscure. On-going phase 3 clinical studies are examining its potential in the management of early diabetic neuropathy.

\section{Nonenzymatic Glycation}

Nonenzymatic protein glycation ${ }^{150}$ is a well-established mechanism by which glucose and its metabolites may exert detrimental effects in diabetes by a process which may be exacerbated by increased flux through the polyol pathway as fructose, and some of its triose-phosphate metabolites are much stronger glycating agents than glucose on a molar basis. ${ }^{68}$ In keeping with this is the evidence that an ARI has been shown to effect the fluorescence level of endoneurial extracellular matrix from diabetic rats ${ }^{151}$ and aminoguanidine, a glycation inhibitor, partially protects against the nerve conduction slowing and nerve fibre damage in chronically diabetic rats. ${ }^{152}$ Potentially, excess protein glycation in diabetes could have detrimental effects on the endoneurial 
microenvironment either by damaging the vascular supply, or by directly altering the composition of the extracellular matrix. Schwann cells and/or regenerating axons interact with extracellular proteins via specific membrane 'substrate adhesion molecules' or 'SAMS' which may also be an important modulation of neurotrophism. ${ }^{153-155}$ This is reflected by the inability of laminin to support neurite outgrowth in tissue culture, after the laminin underwent chemical glycation. ${ }^{156}$ Therefore the nonenzymatic glycation of extracellular matrix proteins could interfere with their ability to exert neurotrophic effects on peripheral nerve fibres.

\section{Growth Factors}

Recent advances in the treatment of drug-induced neuropathies with neurotrophic agents have rekindled interest in neurotrophism and, in particular, the potential role of neurotrophic factors in the pathogenesis and treatment of diabetic neuropathy.

The prototypic neurotrophic agent is NGF, discovered by Levi-Montaicini and Hamburg. ${ }^{157} \mathrm{NGF}$ is produced by target organs of autonomic and sensory neurons where levels of NGF mRNA parallel the density of innervation by NGF-sensitive neurons. ${ }^{157,158}$ Retrograde transport of NGF from target organs to neuronal cell bodies is required for normal growth, maintenance, and regeneration of the peripheral nervous system. Recently, there is strong evidence suggesting that adult Schwann cells also make growth factors and express growth factor receptors during neuronal development. ${ }^{159,160}$ These growth factors include not only NGF but also ciliary neurotrophic factor (CNTF) and IGF-I.

Potential blunting of normal neurotrophic responses could play a role in the pathogenesis of diabetic neuropathy. Persistent hyperglycaemia may:

1. decrease growth factor synthesis by target organs;

2. disrupt retrograde transport of growth factors to the neuronal cell body;

3. affect the signal transduction mechanism of growth factors in neurons; or

4. alter the ability of neurons or Schwann cells to produce growth factors required for normal cell maintenance.

Current data indicate all four possibilities may contribute, either individually or collectively, to the pathogenesis of diabetic neuropathy.

\section{Growth Factor Synthesis by Target Organs}

It has been recognized for many years that trophic substances in the nervous system could influence the developmental fate of a neuron. The best studied of these is NGF, a protein produced by target cells of sympathetic and neural-crest derived sensory neurons. After retrograde axonal transport, NGF can induce enzymes required for neurotransmitter synthesis, protein phosphorylation, methylation, and gene expression of ras-like proteins in neurons. NGF is required for normal function of these neurons in embryonic, postnatal, and adult life, and loss of NGF leads to neuronal dysfunction. These same NGF requiring sensory neurons, are commonly affected in diabetes, producing autonomic and/ or sensory neuropathy(s). Evidence suggests that NGF may play a role in the pathophysiology of these neuropathies. Endogenous NGF levels are reduced in sympathetically innervated target organs of streptozotocin-treated rats. ${ }^{161}$ In both streptozotocin-treated rats as well as genetically diabetic mice (C57BL/Ks) db/db), there is a profound decrease of NGF production by the submandibular glands. ${ }^{162}$ In humans, patients with diabetic neuropathy have significantly lower levels of serum NGF than non-diabetic controls. ${ }^{163}$ These data all suggest that growth factor production is altered in diabetes, and such a disruption of normal neurotrophic factor production may play a role in the pathogenesis of diabetic neuropathy.

\section{Axonal Transport of Growth Factors}

NGF binds selectively to the terminal proteins of sympathetic and neural crest-derived sensory neurons, and, after internalization, is transported by retrograde axonal flow to the cell bodies. This transport is altered in streptozotocin diabetic rats. Mesenteric nerves, which supply the alimentary tract, can develop a distal diabetic axonopathy. During experimentally induced diabetes, retrograde axonal transport of NGF along the mesenteric nerves to the superior mesenteric ganglion is reduced by approximately half. ${ }^{164}$ Similarly, NGF transport is decreased in diabetic somatic sensory neurons. ${ }^{165}$ These alterations in NGF transport form a subset of more widespread transport dysfunction in diabetes. Decreased axonal transport during experimentally induced diabetes has been reported for proteins, glycoproteins, and neurotransmitters. ${ }^{164}$ These results suggest that impairment of axonal transport, especially the retrograde flow of growth factors, may play a role in the pathogenesis of diabetic neuropathy.

\section{Signal Transduction of Crowth Factors in Diabetes}

In neural tissues, activation of muscarinic, cholinergic, adrenergic, histaminergic or serotergic receptors results in stimulation of PI turnover. ${ }^{166}$ Interestingly, not only have neurotransmitters been linked to PI turnover but NGF has also been shown to stimulate PI turnover in rat superior cervical ganglia ${ }^{167}$ and $\mathrm{PCl} 2$ cells. ${ }^{168}$ The most extensively studied growth factor which can be coupled to $\mathrm{PI}$ turnover is, however, epidermal growth factor (EGF). When EGF binds to its receptor on the A431 cell, there is an increase in $\mathrm{PI}$ turnover, ${ }^{169}$ followed by an increase in intracellular calcium, and PKC mediated 
phosphorylation of the EGF receptor. ${ }^{170}$ Recently, IGFII has been shown to stimulate $\mathrm{IP}_{3}$ and DAG production in proximal tubular basolateral membranes from canine kidney; ${ }^{171}$ mannose-6-phosphate may potentiate this stimulation, ${ }^{172}$ reflecting a potential role for carbohydrate moieties in the regulation of growth factor signal transduction.

Although alterations in PI metabolism are well documented in diabetes, much less is known about the potential role growth factors may play in these alterations. The definitive experiments, examining growth factor coupled PI turnover in multiple diabetic tissues, have not been done.

\section{Growth Factor Production}

In adult rat sciatic nerve, NGF production is low, as long as axonal contact is maintained. ${ }^{173,174}$ With nerve transection, Schwann cells distal to the cut, including those which ensheath motor axons, dramatically increase their production of $\mathrm{NGF}^{175}$ and NGF receptors, ${ }^{176,177}$ reaching a maximal at 5 to 7 days. Transection of selective ventral roots entering the sciatic nerve results in increased NGF receptor expression by Schwann cells associated with degenerating motor neurons alone, but not intact sensory neurons. ${ }^{177}$ Analogous to axonal regeneration, Schwann cells express NGF receptors during normal development with a dramatic decline in receptor number (25-fold) upon PNS maturation. ${ }^{160}$

Schwann cells have also been implicated as local producers of CNTF and IGF-I. Motor neurons serve as the major target for CNTF, a small polypeptide originally purified from chick and rabbit sciatic nerve. ${ }^{178}$ CNTF enhances avian motor neuron survival both in vivo and in vitro and can rescue neonatal rat facial motor neurons from experimentally induced cell death. ${ }^{179,180}$ IGF-I immunoreactivity is present in Schwann cell cytoplasm and is increased by sciatic nerve transection. ${ }^{181}$ Addition of IGF-I to freeze injured sciatic nerves enhances regeneration in a dose-dependent fashion. ${ }^{182}$ In streptozotocin-treated rats, there is a decrease in serum $\mid G F-1$ levels ${ }^{183-185}$ and a reduction in IGF-I mRNA in liver, kidney, lung, and heart. ${ }^{184,186,187}$

The effects of diabetes on nervous system expression of NGF, IGF-I or CNTF remains however unknown. Successful axonal maintenance, regeneration, and reformation of axon-Schwann cell contacts is likely to be dependent on this local synthesis of growth factors and growth factor receptors. ${ }^{173}$ Blunted neurotrophic effects may occur in diabetes and contribute to the pathogenesis of diabetic neuropathy. Currently, these ideas remain untested and further work in this field is required.

\section{Concluding Remarks}

In summary, all of the above abnormalities identified in diabetes, can be traced to the metabolic effects of hyperglycaemia and/or other effects of insulin deficiency on the richly varied cell constituents of peripheral nerve, its supporting connective tissue and vascular elements, and possibly the autonomic innervation that controls the endoneurial blood flow. Considerable evidence appears to link both the metabolic and vascular hypotheses of diabetic neuropathy. For example, increased glucose flux through the polyol pathway may be deleterious in diabetes by precipitating osmotic dysregulation in tissue with high levels of AR2 activity when myo-inositol and taurine depletion may become rate limiting for their normal metabolic functions; producing redox perturbations manifest as oxidation and reduction of the $\mathrm{NADPH} / \mathrm{NADP}^{+}$and $\mathrm{NADH} / \mathrm{NAD}^{+}$redox couples, respectively, and increasing nonenzymatic protein glycation. These metabolic perturbations may potentially lead to alterations in nerve blood flow due to disruption of sympathetic tone and disturbances in the production of vascoactive factors. Alterations in fatty acid metabolism in diabetes may directly disrupt nerve structure and function but also may disturb the production of vasodilating eicosanoids. In addition, accumulating evidence implicates a role for blunted neurotrophism in the development of diabetic neuropathy.

Although the diverse effects of hyperglycaemia, at first glance, appear to preclude the development of an effective therapeutic strategy in the management of this chronic complication, the interdependence of the many factors which are necessary for normal nerve function suggests that selective intervention aimed at a key defect early in this cascade may correct many of the later defects as has been observed by the wide ranging effects of the ARIs.

\section{References}

1. The DCCT Research Group. Factors in the development of diabetic neuropathy: baseline analysis of neuropathy in the feasibility phase of the Diabetes Control and Complications Trial (DCCT). Diabetes 1988; 37: 476-481.

2. Pirart J. Diabetes mellitus and its degenerative complications: a prospective study of 4,400 patients observed between 1947 and 1973. Diabetes Care 1978; 1: 168-188

3. Young MI, Boulton AJM, Macleod AF, Williams DRR Sonksen PH. A multicentre study of the prevalence of diabetic peripheral neuropathy in the United Kingdom hospital clinic population. Diabetologia 1993; 36: 150-154.

4. Brand PW. The diabetic foot. In: Ellenberg M, Rifkin $H$, eds. Diabetes Mellitus. New York: Medical Examination Publishing Co., Inc., 1982: 829-849.

5. Greene DA, Sima AAF, Stevens MJ, Feldman EL, Lattimer SA. Complications: neuropathy, pathogenetic considerations. Diabetes Care 1992; 15: 1902-1925.

6. Greene DA, Sima AAF, Pfeifer MA, Albers JW. Diabetic neuropathy. Ann Rev Med 1990; 41: 303-317.

7. Thomas PK, Lascelles RG. The pathology of diabetic neuropathy. Q / Med 1966; 35: 489-909.

8. Bischoff A. Diabetic neuropathy. Pathologic anatomy, pathophysiology and pathogenesis on the basis of 
electron microscopic studies. Disch Med Wochenschr 1968; 93: 237-241.

9. DCCT Research Group. The effect of intensive treatment of diabetes on the development and progression of long-term complications in insulin-dependent diabetes mellitus. N Eng/ / Med 1993; 329: 977-986.

10. Greene DA, Lattimer SA, Sima AAF. Sorbitol, phosphoinositides and sodium-potassium-ATPase in the pathogenesis of diabetic complications. N Eng / Med 1987; 316: 599-606.

11. Dvornik D. Hyperglycemia in the pathogenesis of diabetic complications. In: D. Porte, ed. Aldose Reductase Inhibition. An Approach to the Prevention of Diabetic Complications. New York: Biomedical Information Corporation, 1987: 69-151.

12. Low PA, Tuck RR, Takeuchi M. Nerve microenvironment in diabetic neuropathy. In: Dyck PJ, Thomas PK, Asbury AK, Winegrad AI, Porte D Ir, eds. Diabetic Neuropathy. Philadelphia: Saunders, 1987: 266-278.

13. Cameron NE, Cotter MA, Low PA. Nerve blood flow in early experimental diabetes in rats: relation to conduction deficits. Am / Physiol 1991: 261: E1-E8.

14. Cameron NE, Cotter MA, Ferguson $\mathrm{K}$, Robertson $\mathrm{S}$, Radcliffe MA. Effects of chronic alpha-adrenergic receptor blockade on peripheral nerve conduction, hypoxic resistance, polyols, Na/K-ATPase activity, and vascular supply in STZ-D rats. Diabetes 1991; 40: 1652-1658.

15. Cameron NE, Cotter MA, Robertson S. Angiotensin converting enzyme inhibition prevents development of muscle and nerve dysfunction and stimulated angiogenesis in streptozotocin-diabetic rats. Diabetologia 1992; 35: 12-18.

16. Greene DA, Lattimer SA, Sima AAF. Pathogenesis and prevention of diabetic neuropathy. Diabet Metab Rev 1988; 4: 201-221.

17. Marano CQ, Matchinsky FM. Biochemical aspects of diabetes mellitus in microscopic layers of the cornea and retina. Diabet Metab Rev 1989; 5: 1-15.

18. Greene DA, Lattimer SA, Sima AAF. Pathogenesis of diabetic neuropathy, role of altered phosphoinositide metabolism. Crit Rev Neurobiol 1989; 5: 143-219.

19. Stevens MJ, Lattimer SA, Kamijo M, VanHuysen C, Sima AAF, Greene DA. Osmotically induced nerve taurine depletion and the compatible osmolyte hypothesis in experimental diabetic neuropathy. Diabetologia 1993; 36: 608-614

20. Greene DA, Winegrad AI. Effects of acute experimental diabetes on composite energy metabolism in peripheral nerve axons and Schwann cells. Diabetes 1981; 30: 967-974.

21. Greene DA. Metabolic abnormalities in diabetic peripheral nerve: relation to impaired function. Metabolism 1983; 32: 118-125

22. Greene DA, Lattimer SA. Impaired energy utilization and NA-K-ATPase in diabetic peripheral nerve. Am J Physiol 1984; 246: E311-E318.

23. Greene DA, Delesus PV, Winegrad Al. Effects of insulin and dietary myo-inositol on impaired motor nerve conduction velocity in acute streptozotocin diabetes. I Clin Invest 1975; 55: 1326-1336.

24. Greene DA, Yagihashi S, Lattimer SA, Sima AAF. Nerve $\mathrm{NA}^{+}-\mathrm{K}^{+}$-ATPase, conduction and myoinositol in the insulin deficient BB rat. Am / Physiol 1984, 247: E534-E539.

25. Greene DA, Chakrabarti S, Lattimer SA, Sikma AAF. Role of sorbitol accumulation and myoinositol depletion in paranodal swelling of large myelinated nerve fibers in the insulin-deficient spontaneously diabetic biobreeding rat. I Clin Invest 1987; 79: 1479-1485.
26. Greene DA, Lattimer S, Ulbrecht J, Carroll P. Glucoseinduced alterations in nerve metabolism: current perspective on the pathogenesis of diabetic neuropathy and future directions for research and therapy. Diabetes Care $1985 ; 8: 290-299$

27. Tomlinson DR, Sidenius P, Larsen IR. Slow componenta of axonal transport, nerve myo-inositol and aldose reductase inhibition in streptozotocin-diabetic rats. Diabetes $1986 ; 34: 398-402$.

28. Finegold D, Lattimer S, Nolle S, Bernstein M, Greene DA. Polyol pathway activity and myo-inositol metabolism. Diabetes 1983; 32: 988-992.

29. Mayer $\mathrm{JH}$, Tomlinson DR. The influence of aldose reductase inhibition and nerve myoinositol on axonal transport and nerve conduction velocity in rats with experimental diabetes. I Physiol (London) 1983; 340: 25P-26P

30. Greene DA, Lattimer SA. Action of sorbinil in diabetic peripheral nerve. Relationship of polyol (sorbitol) pathway inhibition to a myo-inositol-mediated defect in sodium-potassium ATPase activity. Diabetes 1984; 33: $712-716$

31. Tomlinson DR, Mayer JH. Reversal of deficits in axonal transport and nerve conduction velocity by treatment of streptozotocin diabetic rats with myo-inositol. Exp Neurol 1985; 89: 420-427.

32. Gillon KRW, Hawthorne JN. Sorbitol, inositol and nerve conduction in diabetes. Life Sci 1983; 32: 1943-1947.

33. Zhu X, Eichberg 1. 1,2-diacylglycerol content and its arachidonyl-containing molecular species are reduced in sciatic nerve from streptozotocin-induced diabetic rats. I Neurochem 1990; 55: 1087-1090.

34. Kim J, Kyriazi H, Greene DA. Normalization of $\mathrm{Na}, \mathrm{K}$ ATPase activity in isolated membrane fraction from sciatic nerves of streptozotocin-induced diabetic rats by dietary myo-inositol supplementation in vivo or protein kinase $C$ agonists in vitro. Diabetes $1991 ;$ 40: 558-567.

35. Lattimer SA, Sima AAF, Greene DA. In vitro correction of impaired $\mathrm{Na}^{+}-\mathrm{K}^{+}$-ATPase in diabetic nerve by protein kinase $C$ agonists. Am / Physiol 1989; 256: E264-E269.

36. Greene DA, Lattimer-Greene SA, Sima AAF. Pathogenesis of diabetic neuropathy: role of altered phosphoinositide metabolism. Critical Reviews in Neurobiology 1989; 5: $143-219$

37. Kunisaki $M$, Bursell S-E, Umeda $F$, Nawata $H$, King GL. Normalization of diacylglycerol-protein kinase $C$ activation by vitamin $\mathrm{E}$ in aorta of diabetic rats and cultured rat smooth muscle cells exposed to elevated glucose levels. Diabetes $1994 ; 43$ : 1372-1377.

38. Craven PA, DeRubertis FR. Protein kinase $C$ is activated in glomeruli from streptozotocin diabetic rats: possible mediation by glucose. / Clin Invest 1989; 83: 1667-1675.

39. Hermenegildo C, Felipo V, Minana M-D, Romero FJ, Grisolia S. Sustained recovery of $\mathrm{Na}^{+}-\mathrm{K}^{+}-\mathrm{ATPase}$ activity in sciatic nerve of diabetic mice by administration of $\mathrm{H} 7$ or claphostin C, inhibitors of PKC. Diabetes 1993 42: $257-262$

40. Judzewitsch RG, Jaspan JB, Polonsky KS, Weinberg CR Halter JB, Halar E, et al. Aldose reductase inhibition improves nerve conduction velocity in diabetic patients. N Eng/ / Med 1983; 308: 119-125.

41. Sima AAF, Bril V, Nathanial V, McEwen TA, Brown M Lattimer SA, et al. Regeneration and repair of myelinated fibers in sural nerve biopsies from patients with diabetic neuropathy treated with an ARI. N Engl / Med 1988; 319: 548-555.

42. Dyck PJ, Zimmerman BR, Vilen TH, Minnerath SR, Karnes JL, Yao JK, et al. Nerve glucose, fructose, sorbitol, 
myo-inositol and fiber degeneration and regeneration in diabetic neuropathy. N Engl / Med 1988; 319: 542-548.

43. Das PK, Bray CM, Aguayo AJ, Rasminsky M. Diminished ouabain sensitive, sodium potassium ATPase activity in sciatic nerves of rats with streptozotocin induced diabetes. Exp Neurol 1976; 53: 285-288.

44. Greene DA, Lattimer SA. Impaired rat sciatic nerve sodium-potassium adenosine trisphosphatase in acute streptozotocin diabetes and its correction by dietary myo-inositol supplementation. / Clin Invest 1983; 72: 1058-1063.

45. Simpson CMF, Hawthorne JN. Reduced $\mathrm{Na}^{+}-\mathrm{K}^{+}-\mathrm{ATPase}$ activity in peripheral nerve of streptozotocin-diabetic rats: a role for protein kinase C? Diabetologia 1988; 31: 297-303.

46. Sonobe $M$, Yasuda $H$, Hisanaga $T$, Maeda $K$, Yamashita $\mathrm{M}$, Kawabata $\mathrm{T}$, et al. Amelioration of nerve $\mathrm{Na} / \mathrm{K}$ ATPase activity independently of myo-inositol level by PGE1 analogue OP-1206.a-CD in streptozotocininduced diabetic rats. Diabetes 1991; 40: 726-730.

47. Stevens MJ, Dananberg J, Feldman EL, Lattimer SA, Kamijo $M$, Thomas TP, et al. The linked roles of nitric oxide, aldose reductase and $\left(\mathrm{NA}^{+}, \mathrm{K}^{+}\right)$-ATPase in the slowing of nerve conduction in the streptozotocin diabetic rat. I Clin invest 1994; 94: 853-859.

48. Cameron NE, Cotter MA, Dines KC, Maxfield EK. Pharmacological manipulation of vascular endothleium function in nondiabetic and streptozotocin-diabetic rats: effects on nerve conduction, hypoxic resistance and endoneurial capillarization. Diabetologia 1993; 36: 516-522.

49. Dvornik, D. In: Porte D, ed. Aldose Reductase Inhibition: An Approach to the Prevention of Diabetic Complications. New York: McGraw-Hill, 1987: 222-323.

50. Kinoshita JH. Mechanism initiating cataract formation. Invest Opthalmol 1974; 13: 713-724.

51. Moriyama T, Garcia-Perez A, Burg MB. Factors affecting the ratio of different organic osmolytes in renal medullary cells. Am / Physiol 1990; 259: F847-F858.

52. Yancey P, Clark M, Hand S, Bowlus R, Somero G. Living with water stress: evolution of osmolyte systems. Science 1982; 217: 1214-1222.

53. Bagnasco $S$, Balaban R, Fales $H$, Yang Y.-M, Burg MB. Predominant osmotically active organic solutes in rat and rabbit medullas. / Biol Chem 1986; 261: 5872-5877.

54. Burg MB, Kador PF. Sorbitol, osmoregulation, and the complications of diabetes. I Clin Invest 1988; 81: 635-640.

55. Moriyama T, Garcia-Perez A, Burg MB. Osmotic regulation of aldose reductase protein synthesis in renal medullary cells. I Biol Chem 1989; 264: 16810-16814.

56. Moo Kwon $H$, Yamauchi $A$, Uchida $S$, Robey $R$, Garcia-Perez A, Burg MB, et al. Renal Na-myo-inositol cotransporter mRNA expression in Xenopus oocytes: regulation by hypertonicity. Am / Physiol 1991; 260: F258-F263.

57. Uchida S, Nakanishi T, Moo Kwon H, Preston AS, Handler JS. Taurine behaves as an osmolyte in MadinDarby canine kidney cells. ) Clin Invest 1991; 88: 656-662.

58. Malone II, Lowitt S, Cook WR. Nonosomotic diabetic cataracts. Ped Res 1990; 27: 293-296.

59. Nakamura J, Del Monte MA, Shewach D, Lattimer SA, Greene DA. Inhibition of phosphatidylinositol synthase by glucose in human retinal pigment epithelial cells. Am / Physiol 1992; 262: E417--E426.

60. Huxtable RJ. From heart to hypothesis: a mechanism for the calcium modulatory effects actions of taurine. In: Huxtable RJ, Franconi F, Giotti A, eds. The Biology of Taurine: Methods and Mechanisms. New York: Plenum Press, 1987: 371-388.

61. Lombardi JB. Effects of taurine on calcium ion uptake and protein phoshorylation in rat retinal membrane preparations. I Neurochem 1985; 45: 268-275.

62. Cheung WY. Calmodulin plays a pivotal role in cellular regulation. Science 1980; 207: 17-19.

63. Nestler E), Greengard P. Protein phosphorylation in the brain. Nature 1983; 305: 583-588.

64. Dent M, Tebbs SE, Gonzales AM, Ward JD, Wilson RM. Neutrophil aldose reductase activity and its association with established diabetic microvascular complications. Diabetic Med 1991; 8: 439-442.

65. Hamada $Y$, Kitoh $R$, Raskin $P$. Increased activity of erythrocyte aldose reductase in insulin dependent diabetes with severe diabetic complications. Diabetes 1991; 40(suppl 1): 35.

66. Vinores SA, Campochiaro PA, Williams EH, May EE, Green R, Sorenson RL. Aldose reductase expression in human diabetic retina and retinal pigment epithelium. Diabetes 1988; 37: 1658-1664.

67. Carroll PB, Thornton BM, Greene DA. Glutathione redox state is not the link between polyol pathway activity and diminished ( $\mathrm{Na}, \mathrm{K}$ )-ATPase activity in experimental diabetic neuropathy. Diabetes 1986; 35: 1282-1285.

68. Pugliese G, Tilton RG, Williamson JR. Glucose-induced metabolic imbalances in the pathogenesis of diabetic vascular disease. Diab Metab Rev 1991; 7: 35-59.

69. Low PA, Lagerlund TD, MCManis PG. Nerve blood flow and oxygen delivery in normal, diabetic and ischemic neuropathy. Int Rev Neurobiol 1989; 31: 355-438.

70. Tuck RR, Schmelzer JD, Low PA. Endoneurial blood flow and oxygen tension in the sciatic nerves of rats with experimental diabetic neuropathy. Brain 1984; 107: 935-950.

71. Tilton RG, Pugliese G, Eades DM, Privince MA, Sherman WR, Kilo $C$, et al. Prevention of hemodynamic and vascular albumin filtration changes in diabetic rats by ARIs. Diabetes 1989; 38: 1258-1270.

72. Faberberg S-E. Diabetic neuropathy: a clinical and histological study of the significance of vascular affections. Acta Med Scand 1959; 164(suppl 345): 1-97.

73. Newrick PG, Wilson AJ, Jakubowski J, Boulton AJM, Ward JD. Sural nerve oxygen tension in diabetes. $\mathrm{Br}$ Med / 1986; 293: 1053-1054.

74. Appenzeller O, Parks RD, MacGee J. Peripheral neuropathy in chronic disease of the respiratory tract. Am / Med 1968; 44: 873-880.

75. Faden A, Medoza E, Flynn F. Subclinical neuropathy associated with chronic obstructive pulmonary disease. Possible pathophysiologic role of smoking. Arch Neurol 1981; 38: 639-642.

76. Low PA, Schmelzer JD, Ward KK. Experimental hypoxic neuropathy: relevance to diabetic neuropathy. $A m$ I Physiol 1986; 250: E94-E98.

77. Low PA, Schmelzer JD, Ward KK, Curran GL, Poduslo $J F$. Effect of hyperbaric oxygenation on normal and chronic streptozotocin diabetic peripheral nerves. Exp Neurol 1988; 99: 201-212.

78. Takeuchi M, Low PA. Dynamic peripheral nerve metabolic and blood pressure responses to exsanguination. Am / Phsyiol 1987; 253: E349-E353.

79. Adams WE. The blood supply of nerves. II. The effects of exclusion of its regional sources of supply on the sciatic nerve of the rabbit. / Anat 1943; 77: 243-250.

80. Tesfaye S, Harris N, Jakubowski JI, Mody C, Wilson RM, Renme IG, et al. Impaired blood flow and arteriovenous shunting in human diabetic neuropathy: a 
novel technique of nerve physiology and fluorescein angiography. Diabetologia 1993; 36: 1266-1274.

81. Dyck PJ, Hansen S, Karnes J, O'Brien P, Yasuda $H$, Windebank $A$, et al. Capillary number and percentage closed in human diabetic sural nerve. Proc Natl Acad Sci 1985; 82: 2513-2517.

82. Johnson PC, Doll SC, Cromey DW. Pathogenesis of diabetic neuropathy. Ann Neurol 1986; 19: 450-457.

83. Dyck PJ, Karnes JL, O'Brien P, Okazaki H, Lois A, Engelstad J. The spatial distribution of fiber loss in diabetic polyneuropathy suggests ischemia. Ann Neurol 1986; 19: 440-449.

84. Dyck PJ, Lois A, Karnes JL, O'Brien P, Rizza R. Fiber loss is primary and multifocal in sural nerves in diabetic polyneuropathy. Ann Neurol 1986; 19: 425-435.

85. Vracko R. A comparison of the microvascular lesions in diabetic mellitus with those of normal aging. I Am Geriatr Soc 1982; 30: 201-205.

86. Williams E, Timperley WR, Ward JD, Duckworth T. Electron microscopic studies of vessels in diabetic peripheral neuropathy. / Clin Pathol 1980; 33: 462-470.

87. Sima AAF, Nathaniel V, Prashar A, Bril V, Greene DA. Endoneurial microvessels in human diabetic neuropathy: endothelial cell dysfunction and lack of effect by aldose reductase inhibitor. Diabetes 1991; 40: 1090-1099.

88. Llewelyn JG, Thomas PK, Gilbey SG, Watkins PI, Muddle JR. Pattern of myelinated fibre loss in the sural nerve in neuropathy related to Type 1 (insulin-dependent) diabetes. Diabetologia 1988; 31: 162-167.

89. Schmid-Schonbein $H$, Volger E. Red cell aggregation and red cell deformability in diabetes. Diabetes 1976; 25 (suppl 2): 897-902.

90. Lowe GD, Lowe JM, Drummond MM, Reith S, Belch J), Kesson CM, et al. Blood viscosity in young male diabetics with or without retinopathy. Diabetologia 1980; 18: 359-362.

91. Bauersachs RM, Shaw S, Ziedler A, Meiselman HJ. Red blood cell aggregation and blood viscosity in poorly controlled type 2 diabetes mellitus. Clin Hemorheol 1989; 9: 935-952.

92. MacRury SM, Lockhart JC, Small M, Weir Al, MacCuish $A C$, Lowe GDO. Do rheological variables play a role in diabetic peripheral neuropathy? Diabetic Med 1991; 8: 232-236.

93. Moncada S, Palmer RMJ, Higgs EA. Nitric oxide: physiology, pathophysiology and pharmacology. Pharmacol Rev 1991; 43: 109-141.

94. Ward KK, Low PA, Schmelzer JD, Zochodne DW. Prostacyclin and noradrenaline in peripheral nerve of chronic experimental diabetic in rats. Brain 1989; 112 : 197-208.

95. Garthwaite ). Glutamate, nitric oxide and cell-cell signalling in the nervous system. Trends Neurosci 1991; 14: $60-67$.

96. Garthwaite J, Charles S, Chess-Williams R. Endotheliumderived relaxing factor release on activation of NMDA receptors suggests a role as intercellular messenger in the brain. Nature 1988; 336: 385-388.

97. Moncada S, Palmer RMJ, Higgs EA. Biosynthesis of nitric oxide from l-arginine: a pathway for the regulation of cell function and communication. Biochem Pharmacol 1989; 38: 1709-1715.

98. Saenz de Tejada I, Goldstein I, Azadzoi K, Krane RJ, Cohen RA. Impaired neurogenic and endotheliummediated relaxation of the penile smooth muscle from diabetic men with impotence. N Engl / Med 1989; 320: 1025-1030.

99. Durant W, Amar K, Sen Sunahara FA. Impairment of endothelium-dependent relaxation in aorta from spontaneously diabetic rats. Br / Pharmacol 1988; 94: 463-468.

100. Mayhan WG, Simmons LK, Sharpe GM. Mechanism of impaired responses of cerebral arterioles during diabetes mellitus. Am / Physiol 1991; 260: (Heart Circ Physiol 29) $\mathrm{H} 319-\mathrm{H} 326$

101. Kamata K, Miyata N, Kasuya Y. Impairment of endothelium-dependent relaxation and changes in levels of cyclic GMP in aorta from streptozotocin-induced diabetic rats. Br / Pharmacol 1989; 97: 614-618.

102. Peiper GM, Gross G). Oxygen free radicals abolish endothelium-dependent relaxation in diabetic rat aorta. Am J Physiol 1988; 255: H825-H833.

103. Gryglewski RJ, Palmer RJM, Moncada S. Superoxide anion is involved in the breakdown of endotheliumderived vascular relaxing factor. Nature 1986; 320: 454-456.

104. Rees DD, Palmer RM, Moncada S. Role of endotheliumderived nitric oxide in the regulation of blood pressure. Proc Natl Acad Sci USA 1989; 86: 3375-3378.

105. Vallence $P$, Collier J, Moncada S. Effects of endotheliumderived nitric oxide on peripheral arterial tone in man. Lancet 1989; ii: 997-1000.

106. Calver A, Collier J, Vallance P. Inhibition and stimulation of nitric oxide synthesis in the human forearm arterial bed of patients with insulin-dependent diabetes. $f \mathrm{Clin}$ Invest 1992; 90: 2548-2554.

107. Rapoport RM, Murard F. Agonist-induced endotheliumdependent relaxation in rat thoracic aorta may be mediated through CGMP. Circ Res 1983; 52: 352-357.

108. Furchgott RF, Cherry PD, Zawadzki JV, Jon-Arhianandan D. Endothelial cells as mediators of vasodilatation of arteries. / Cardiovasc Pharmacol 1984; 6(suppl 2): $336-343$.

109. Gupta S, Sussman 1, McArthur CS, Tornheim K, Cohen RA, Ruderman NB. Endothelium-dependent inhibition of $\mathrm{Na} / \mathrm{K}$-ATPase activity in rabbit aorta by hyperglycemia. I Clin Invest 1992; 90: 727-732.

110. Bult H, Boeckxstaens GE, Pelckmans PA, Jordaens FH, Van Maercke YM, Herman AG. Nitric oxide as an inhibitory non-adrenergic non-cholinergic neurotransmitter. Nature (Lond) 1990; 345: 346-347.

111. Cameron NE, Cotter MA. Impaired contraction and relaxation in aorta from streptozotocin-diabetic rats: role of polyol pathway. Diabetologia 1992; 35: 1011-1019.

112. Dvornik D. Hyperglycemia in the pathogenesis of diabetic complications. In: Porte D, ed. Aldose Reductase Inhibition. An Approach to the Prevention of Diabetic Complications. New York: Biomedical Information Corporation, 1987; 69-151.

113. Hogan M, Cerami A, Bucala R. Advanced glycosylation endproducts block the antiproliferative effect of nitric oxide. Role in the vascular and renal complications of diabetes mellitus. / Clin Invest 1992; 90: 1110-1105.

114. Yasuda $\mathrm{H}$, Sonobe $M$, Yamashita $M$, Terada $M$, Hatanaka 1, Huitian Z, et al. Effect of prostaglandin E1 analogue TFC 612 on diabetic neuropathy in streptozotocininduced diabetes rats: comparison with aldose reductase inhibitor ONO 2235. Diabetes 1989; 38: 832-838.

115. Nakane $M$, Mitchel $L$, Forstermann $U$, Murad $F$. Phosphorylation by calcium clamodulin-dependent protein kinase II and protein kinase $\mathrm{C}$ modulates the activity of nitric oxide synthetase. Biochem Biophys Res Commun 1991; 180: 1396-1402.

116. Bredt DS, Ferris CD, Snyder SH. Nitric oxide synthetase regulatory sites. ) Biol Chem 1992; 267: 10976-10981.

117. Murthy KS, Jin J-G, Makhlouf GM. Inhibition of nitric oxide synthase activity in dispersed gastric muscle 
cells by protein kinase. C. Am / Physiol 1994; 266: (Gastrointest Liver Physiol 29): G161-G165.

118. Smith SS, Li J. Novel action of nitric oxide as mediator of $\mathrm{N}$-methyl-d-aspartate-induced phosphatidylinositol hydrolysis in neonatal rat cerebellum. Mol Pharmacol 1992; 43: 1-5.

119. Shimizu K, Muramatsu $M$, Kakegawa $Y$, Asano $H$, Toki $Y$, Miyazaki $Y$, et al. Role of prostaglandin $\mathrm{H} 2$ as an endothelium-derived contracting factor in diabetic state. Diabetes 1993; 42: 1246-1252.

120. Subbiah MTR, Deitemeyer D. Altered synthesis of prostaglandins in platelet and aorta from spontaneously diabetic Wistar rats. Biochem Med 1980; 23: 231-235.

121. Harrison $H E$, Reece $A H$, Johnson $M$. Decreased vascular prostacyclin in experimental diabetes. Life Sci 1978; 23:354-356.

122. Bazan NG. Effects of ischemia and electroconvulsive shock on free fatty acid pool in the brain. Biochimica et Biophysica Acta 1970: 218: 1-10.

123. Wolfe LS. Eicosanoids, prostaglandins, thromboxanes, leukotrienes, and other derivatives of carbon-2 unsaturated fatty acids. I Neurochem 1982; 38: 1-14.

124. Simpson PJ, Mickelson J, Fantone JC, Gallagher KP, Lucchesi BR. Reduction of experimental canine infarct size with prostaglandin E1: inhibition of neutrophil migration and activation. I Pharmacol Exp Therapeut 1988; 244: 619-624.

125. Hedqvist $P$, Wennmalm A. Comparison of the effects of prostaglandins E1, E2 and F2 alpha on the sympathetically stimulated rabbit heart. Acta Physiol Scand 1971; 83: $156-162$.

126. Wennmalm A, Hedqvist P. Inhibition by prostaglandin E1 of parasympathetic neurotransmission in the rabbt heart. Life Sci 1971; 10: 465-470.

127. Shindo $H$, Tawata $M$, Aida $K$, Onaya $T$. The role of cyclic adenosine 3', 5'-monophosphate and polyol metabolism in diabetic neuropathy. / Clin Endocrinol Metab 1992; 74: 393-398.

128. Sonobe $M$, Yasuda $H$, Hisanaga $T$, Maeda $K$, Yamashita $M$, Kawabata $T$, et al. Amelioration of nerve $\mathrm{Na} / \mathrm{K}$ ATPase activity independently of myo-inositol level by PGE1 analogue OP-1206. a-CD in streptozotocininduced diabetic rats. Diabetes 1991; 40: 726-730.

129. Cameron NE, Cotter MA, Robertson S. Effects of essential fatty acid dietary supplementation on peripheral nerve and skeletal muscle function and capillarisation in streptozotocin diabetic rats. Diabetes 1991; 40: 532-539.

130. Houtsmiller AJ, van Hal-Ferwerda J, Zahn KJ, Henkes HE. Favourable influences of linoleic acid on the progression of diabetic micro- and microangiopathy in adult onset diabetes mellitus. Prog Lipid Res 1982; 20: $377-386$.

131. Horrobin DF. Gamma linolenic acid. Rev Contemporary Pharmacotherapy 1990; 1: 1-41.

132. Fritz IB. Carnitine and its role in fatty acid metabolism. Adv Lipid Res 1963; 1: 285-334.

133. McGary JD, Foster DW. Acute reversal of experimental diabetic ketosis in the diabetic rat with $(+)$-decanoylcarntine. / Clin Invest 1973; 52: 877-884.

134. Frohlich J, Seccombe DW, Hahn P, Dodek P, Hynle L. Effect of fasting on free and esterified carnitine levels in human serum and urine: Correlation with serum levels of free fatty acids and $\beta$-hydroxybutyrate. Metabolism 1978; 27: 555-561.

135. Genuth SM, Hoppel CL. Plasma and urine carnitine in diabetic ketosis. Diabetes 1979; 28: 1083-1087.

136. Arduini $A$, Rossi $M$, Mancinelli $G$, Belfiglio $M$, Scurti R. Radatti $G L$, et al. Effect of l-carnitine and acetyl-1- carntine on human erythrocyte membrane stability and deformability. Life Sciences 1990; 47: 2395-2400.

137. Brecher $P$. The interaction of long-chain acyl coA with membranes. Mol Cell Biochem 1983; 57: 3-15.

138. Greene DA, Winegrad AI. In vitro studies of the substrates for energy production and the effects of insulin on glucose utilization in the neural components of peripheral nerve. Diabetes 1979; 28: 878-887.

139. Godin DV, Lopaschuk GD, McNeil JH. Subcellular myocardial abnormalities in experimental diabetes: role of long chain acylcarnitines. Can / Cardiol 1986; 2: 222-229.

140. Lowitt S, Malone JE, Solem A, Kosthals A. Acetylcarnitine improves neuronal function in streptozotocin (STZ) diabetic rats. Diabetes 1990; 39: 155A.

141. Pacifici L, Bellucci A, Piovesan P, Maaccari F, Gorio A, Ramaci MT. Counteraction on experimentally induced diabetic neuropathy by levocarnitine acetyl. Int I Clin Pharm Res 1992; 12: 231-236.

142. Williamson JR, Arrigoni-Martelli E. The roles of glucoseinduced metabolic hypoxia and imbalances in carnitine metabolism in mediating diabetes induced vascular dysfunction. Int / Clin Pharm Res 1992; 12: 247-252.

143. Taglialatela G, Angelucci L, Ramacci MT, WerrbachPerez K, Jackson GR, Perez-Polo JR. Acetyl l-carnitine enhances the response of PC 12 cells to nerve growth factor. Brain Res Dev Brain Res 1991; 59: 221-230.

144. Greene LA, Tischler AS. PC12 phaeochromocytoma cultures in neurobiological research. Adv Cell Neurobiol 1982; 3: 373-414.

145. Fernandez E, Pallini R, Gangitano C, Delfa A, Sangiacomo CO,Sbriccoli A, et al. Effects of l-carnitine, l-acetyl 1-carnitine and gangliosides on the regeneration of the transected sciatic nerve in rats. Neurol Res 1989; 11: $57-62$.

146. Imperato A, Scrocco MG, Ghirardi O, Ramacci MT, Angeluci L. In vivo probing of the brain cholinergic system in the aged rat: Effects of long term acetyl-1carnitine. Annals NY Acad Sci 1991; 621: 90-97.

147. McCaman RE, McCaman RW, Stafford ML. Carnitine acetyltransferase in nervous tissue. / Biol Chem 1966; 241: 930-934.

148. Janiri L, Tempesta E. A pharmacological profile of the effects of carnitine and acetylcarnitine on the central nervous system. Int / Clin Pharmacol Res 1983; 3: 295-306.

149. Williamson JR, Chang K, Frangos $M$, Hasan KS, Ido $Y$, Kawamura JR, et al. Hyperglcemic 'pseudohypoxia' and diabetic complications. Diabetes 1993; 42: 801-813.

150. Brownlee $M$. Glycation products and the pathogenesis of diabetic complications. Diabetes Care 1992; 15: 1835-1843.

151. Richard S, Tamas C, Sell DR, Monnier VM. Tissuespecific effects of aldose reductase inhibition on fluorescence and cross-linking of extracellular matrix in chronic galactosemia. Relationship to pentosidine crosslinks. Diabetes 1991; 40: 1049-1056.

152. Yagihashi S, Kamijo M Baba M, Yagihashi N, Nagai $K$. Effect of aminoguanidine on functional and structural abnormalities in peripheral nerve of STZ-induced diabetic rats. Diabetes 1992; 41: 47-52.

153. Grumet $M$. Structure, expression, and function of $\mathrm{Ng}$ CAM, a member of the immunoglobulin superfamily involved in neuron-neuron and neuron-glia adhesion. I Neurosci Res 1992; 31: 1-13.

154. Daston MM, Ratner N. Expression of P30, a protein with adhesive properties, in Schwann cells and neurons of the developing and regenerating peripheral nerve. I Cell Biol 1991; 112: 1229-1239. 
155. Wood PM, Schachner $M$, Bunge RP. Inhibition of Schwann cell myelination in vitro by antibody to the L1 adhesion molecule. I Neurosci 1990; 10: 3635-3645.

156. Haitoglou CS, Tsilibary EC, Brownlee M, Charonis AS Altered cellular interactions between endothelial celis and nonenzymatically glucosylated laminin/type IV collagen. I Biol Chem 1992; 267: 12404-12407.

157. Levi-Montaicini R, Calissano P. Nerve growth factor as a paradigm for other polypeptide growth factors. Trends Neurosci 1986; 9: 473-477.

158. Thoenen $\mathrm{H}$, Bandtlow $\mathrm{C}$, Heumann R. The physiological function of nerve growth factor in the central nervous system: comparison with the periphery. Rev Physiol Biochem Pharmacol 1987; 109: 146-178.

159. Scarpini E, Ross AH, Rosen JL, Brown MJ, Rostami A, Koprowski $\mathrm{H}$, et al. Expression of nerve growth factor receptor during human peripheral nerve development. Dev Biol 1988; 125: 301-310.

160. Yan $Q$, Johnson EM. A quantitative study of the developmental expression of nerve growth factor (NGF) receptor in rats. Dev Biol 1987; 121: 139-148.

161. Hellweg R, Hartung H-D. Endogenous levels of nerve growth factor (NGF) are altered in experimental diabetes mellitus: A possible role for NGF in the pathogenesis of diabetic neuropathy. I Neurosci Res 1990; 26: 258-267.

162. Kasayama S, Oka T. Impaired production of nerve growth factor in the submandibular gland of diabetic mice. Am / Physiol 1989; 257: E400-E404.

163. Faradji $\mathrm{V}$, Sotelo J. Low serum levels of nerve growth factor in diabetic neuropathy. Acta Neurol Scand 1990; 81: $402-406$.

164. Tomlinson DR, Mayer JH. Defects of axonal transport in diabetes mellitus-a possible contribution to the aetiology of diabetic neuropathy. I Aut Pharmacol 1984; 4: 59-72.

165. Jakobsen J, Brimijoin S, Skau K, Sidepius P, Wells D. Retrograde axonal transport of transmitter enzmes, fucose-labeled protein, and nerve growth factor in streptozotocin-diabetic rats. Diabetes 1981; 30: 797-803.

166. Fisher SK, Heacock AM, Agranoff BW. Inositol lipids and signal transduction in the nervous system: An update. I Neurochem 1992; 58: 18-38.

167. Lakshmanan J. Post-synaptic Pl-effect of nerve growth factor in rat superior cervical ganglia. I Neurochem 1979; 32: 1599-1601.

168. Traynor AE, Schubert D, Allen WR. Alterations of lipid metabolism in response to nerve growth factor. I Neurochem 1982; 39: 1677-1683.

169. Pike LJ, Eakes AT. Epidermal growth factor stimulates the production of phosphatidylinositol monophosphate and the breakdown of polyphosphoinositides in A431 cells. J Biol Chem 1987; 262: 1644-1651.

170. Wahl M, Carpenter G. Regulation of epidermal growth factor-stimulated formation of inositol phosphates in A431 cells by calcium and protein kinase $C$. I Biol Chem 1988; 263: 7581-7590.

171. Rogers SA, Hammerman MR. Insulin-like growth factor II stimulates production of inositol trisphosphate in proximal tubular basolateral membranes from canine kidney. Proc Natl Acad Sci USA 1988; 85: 4037-4041.

172. Rogers SA, Hammerman MR. Mannose-6-phosphate potentiates insulin-like growth factor II-stimulated inositol trisphosphate production in proximal tubular basolateral membranes. / Biol Chem 1989; 264: 4273-4276.

173. Johnson EM, Taniuchi M, DiStefano PA. Expression and possible function of nerve growth factor receptors on Schwann Cells. Trends Neurosci 1988; 111: 299-304.

174. Bosch EP, Zhong W, Lim R. Axonal signals regulate expression of glia maturation factor-b in Schwann cells: an immunohistochemical study of injured sciatic nerves and cultured Schwann cells. / Neurosci 1989; 9: 3690-3698.

175. Heumann $\mathrm{R}$, Korsching $\mathrm{S}$, Bandtlow $\mathrm{C}$, Thoenen $\mathrm{H}$. Changes of nerve growth factor synthesis in nonneuronal cells in response to sciatic nerve transection. / Cell Biol 1987: 104: 1623-1631.

176. Taniuchi $M$, Clark Brent $H$, Johnson EM. Induction of nerve growth factor receptor in Schwann cells after axotomy. Proc Natl Acad Sci USA 1986; 83: 4094-4098.

177. Taniuchi M, Clark HB, Schweitzer JB, Johnson EJ. Expression of nerve growth factor receptors by Schwann cells of axotomized peripheral nerves: ultrastructural location, suppression by axonal contact, and binding properties. I Neurosci 1988; 8: 664681 .

178. Arakawa $Y$, Sendtner $M$, Thoenen $H$. Survival effect of ciliary neurotrophic factor (CNTF) on chick embryonic motoneurons in culture: comparison with other neurotrophic factors and cytokines. I Neurosci 1990; 10: 3507-3515.

179. Oppenheim RW, Prevette D, Qin-Wei Y, Collins F, MacDonald J. Control by embryonic motorneuron survival in vivo by ciliary neurotrophic factor. Science 1991; 252: 1616-1618.

180. Sendtner $M$, Kreutzberg GW, Thoenen $H$. Ciliary neurotrophic factor prevents the degeneration of motor neurons after axotomy. Nature 1990; 345: 440-441.

181. Hansson HA, Dahlin LB, Danielsen N, Fryklund L, Nachemson AK, Polleryd $P$, et al. Evidence indicating trophic importance of IGF-I in regenerating peripheral nerves. Acta Physiol Scand 1986; 126: 609-614.

182. Sjoberg J, Kanje M. Insulin-like growth factor (IGF-I) as a stimulator of regeneration in the freeze-injured rat sciatic nerve. Brain Res 1989; 485: 102-108.

183. Ekstrom AR, Kanje $M$, Skottner A. Nerve regeneration and serum levels of insulin-like growth factor-I in rats with streptozotocin-induced insulin deficiency. Brain Res 1989; 496: 141-147.

184. Yang H, Scheff AJ, Schalch DS. Effects of streptozotocininduced diabetes mellitus on growth and hepatic insulinlike growth factor 1 gene expression in the rat. Metabolism 1990; 39: 295-301.

185. Graubert MD, Goldstein S, Phillips LS. Nutrition and somatomedin: XXVII. Total and free IGF-I and IGF binding proteins in rats with streptozocin-induced diabetes. Diabetes 1991; 40: 959-965.

186. Bornfeldt KE, Arnqvist $\mathrm{JH}$, Enberg B, Matthews LS, Norstedt G. Regulation of insulin-like growth factor-I and growth hormone receptor gene expression by diabetes and nutritional state in rat tissues. I Endocrinol 1989; 122: 651-656.

187. Luo J, Murphy LJ. Differential expression of insulin-like growth factor-1 and insulin-like growth factor binding protein-1 in the diabetic rat. Mol Cell Biochem 1991; 103: $41-50$ 